\author{
N.A. Kargina ${ }^{1}$, V.N. Fomin ${ }^{2}$ \\ ${ }^{I}$ Zh. Abishev Chemical and Metallurgical Institute, Karaganda, Kazakhstan; \\ ${ }^{2}$ Ye.A. Buketov Karaganda State University, Kazakhstan \\ (E-mail:nat-ya1@mail.ru)
}

\title{
Development of the technological process of processing chromium-containing technogenic materials
}

\begin{abstract}
The article is devoted to the development of the technological process for the processing chromium containing technogenic materials, which includes their roasting in the presence of sodium carbonate and the subsequent leaching of chromium from the sinter with water. Using the method of stochastic determinated design of the experiment, a five-factor mathematical model of extracting chromium into a cake was obtained. It is determined that in order to achieve the minimum recovery of chromium in the cake and, accordingly, the most complete isolation of the given metal into the solution, it is necessary to conduct batch roasting under the following conditions: $\mathrm{t}_{\text {roast. }}=960{ }^{\circ} \mathrm{C}, \tau_{\text {roast. }}=3 \mathrm{~h}, \mathrm{~N}=60 \%$, and leaching at $\tau_{\text {leach. }}=2 \mathrm{~h}$ and $\mathrm{t}_{\text {leach. }}=60{ }^{\circ} \mathrm{C}$. The chemistry of the passing processes is shown. It is shown the usefulness of the obtained mathematical equation for making predictions that are more accurate when introducing the values of the arguments within the given limits of their variation into the given equation and less accurate at a considerable distance from these limits. Calculation in the indicated calcination conditions shows that the recovery of chromium in the solution increases with increasing firing temperature, time of its maintenance and consumption of $\mathrm{Na}_{2} \mathrm{CO}_{3}$.
\end{abstract}

Keywords: chromite, stochastic determinated design of the experiment, chromium leaching, sodium carbonate, sodium chromate, industrial chromium containing wastes, chromite calcination, firing of chromiumcontaining batch.

Products with substandard chromium content and the wastes such as dust, slimes and cakes are formed in the production of chromium, its chemical compounds and alloys with various metals [1-3]. Involvement of these wastes in the process of conversion is an important and urgent task [4-7].

A commercial product containing wt. \%: $20.7 \mathrm{Cr} ; 6.31 \mathrm{Fe} ; 34.38 \mathrm{MgO} ; 0.6 \mathrm{CaO} ; 20.9 \mathrm{SiO}_{2} ; 2.86 \mathrm{Al}_{2} \mathrm{O}_{3}$ was selected as an object of research. The experiments were carried out according to the scheme such as roasting of industrial products in the presence of sodium carbonate, leaching of chromium with water from the cake (the ratio of L:S in all experiments was 4:1). The method of stochastic-determinated design of experiment in the modified version was used [8]. In the six-factor plan of the experiment the following factors such as the roasting temperature $\left(t_{\text {roast., }}{ }^{\circ} \mathrm{C}\right)$, roasting time $\left(\tau_{\text {roast. }}, \mathrm{h}\right)$, consumption of sodium carbonate taken with respect to the weight of the commercial product $(N, \%)$, time $\left(\tau_{\text {leach. }}, \mathrm{h}\right)$ and temperature $\left(t_{\text {leach }} .,{ }^{\circ} \mathrm{C}\right)$ of leaching were varied. The position for one factor in the experiment's plan remained unoccupied, which is the vacant factor (Table 1).

Table 1

Plan of the experiment, results of the experiments $\left(\beta_{\text {c.ex., }} \beta_{c / b . e x}, C r_{\text {c.ex., }}, \varepsilon_{\text {c.ex. }}\right)$ and calculations $\left(\beta_{\mathrm{s} . t}, \beta_{\mathrm{c} / \mathrm{bt},}, \mathrm{Cr}_{\mathrm{c.t.}}, \varepsilon_{\mathrm{c} \text {.t. }}\right)$. $R$ is correlation coefficient and $t_{R}$ is its significance

\begin{tabular}{|c|c|c|c|c|c|c|c|c|c|c|c|c|c|c|}
\hline & ${ }^{t_{\text {roast. }},}$ & $\begin{array}{c}\tau_{\text {roast. }}, \\
\mathrm{h}\end{array}$ & $\begin{array}{l}\mathrm{N}, \\
\%\end{array}$ & $\begin{array}{l}\tau_{1}, \\
h\end{array}$ & $\begin{array}{l}\tau_{1}, \\
{ }^{0} \mathrm{C}\end{array}$ & $x_{6}$ & $\begin{array}{c}\beta_{\text {s.ex }}, \\
\%\end{array}$ & $\begin{array}{c}\beta_{\text {s.t, }} \\
\%\end{array}$ & $\begin{array}{c}\beta_{\text {clb.ex., }} \\
\%\end{array}$ & $\begin{array}{c}\beta_{c / b . t .}, \\
\%\end{array}$ & $\begin{array}{c}\mathrm{Cr}_{\text {c.ex., }} \\
\%\end{array}$ & $\begin{array}{c}\mathrm{Cr}_{\text {cake.t., }} \\
\% \text {. }\end{array}$ & $\begin{array}{c}\varepsilon_{\text {c.ex. }}, \\
\%\end{array}$ & $\begin{array}{c}\varepsilon_{\text {c.t.t. }}, \\
\%\end{array}$ \\
\hline 1 & 2 & 3 & 4 & 5 & 6 & 7 & 8 & 9 & 10 & 11 & 12 & 13 & 14 & 15 \\
\hline 1 & 560 & 1 & 20 & 1 & 20 & 1 & 94.33 & 94.67 & 70.22 & 68.20 & 21.94 & 24.08 & 89.03 & 94.2 \\
\hline 2 & 560 & 1.5 & 30 & 1.5 & 40 & 2 & 95.98 & 96.75 & 64.61 & 68.98 & 23.02 & 22.68 & 93.41 & 96.45 \\
\hline 3 & 560 & 2 & 40 & 2 & 60 & 3 & 95.36 & 95.96 & 65.71 & 67.84 & 19.67 & 20.78 & 87.15 & 93.44 \\
\hline 4 & 560 & 2.5 & 50 & 2.5 & 80 & 4 & 93.80 & 93.63 & 64.11 & 66.37 & 17.98 & 18.58 & 83.38 & 87.91 \\
\hline 5 & 560 & 3 & 60 & 3 & 95 & 5 & 91.79 & 90.42 & 60.12 & 65.60 & 20.33 & 16.05 & 94.28 & 80.68 \\
\hline 6 & 660 & 1 & 30 & 2 & 80 & 5 & 92.84 & 93.76 & 76.92 & 74.73 & 18.71 & 17.35 & 90.38 & 79.81 \\
\hline 7 & 660 & 1.5 & 40 & 2.5 & 95 & 1 & 92.04 & 92.99 & 71.43 & 65.28 & 18.15 & 19.5 & 87.68 & 84.21 \\
\hline 8 & 660 & 2 & 50 & 3 & 20 & 2 & 90.43 & 90.73 & 64.21 & 60.48 & 15.55 & 16.78 & 72.11 & 71.98 \\
\hline 9 & 660 & 2.5 & 60 & 1 & 40 & 3 & 88.42 & 87.62 & 62.51 & 66.31 & 17.4 & 14.75 & 84.06 & 74.57 \\
\hline 10 & 660 & 3 & 20 & 1.5 & 60 & 4 & 88.88 & 87.52 & 83.31 & 87.92 & 19.26 & 18.93 & 93.04 & 95.28 \\
\hline 11 & 760 & 1 & 40 & 3 & 40 & 4 & 89.55 & 90.64 & 62.96 & 68.89 & 15.92 & 12.77 & 67.68 & 57.93 \\
\hline 12 & 760 & 1.5 & 50 & 1 & 60 & 5 & 87.78 & 88.43 & 56.11 & 63.30 & 16.29 & 15.21 & 66.1 & 68.19 \\
\hline
\end{tabular}


Development of the technological process ...

Continuation of $\mathrm{Table} 1$

\begin{tabular}{|c|c|c|c|c|c|c|c|c|c|c|c|c|c|c|}
\hline 1 & 2 & 3 & 4 & 5 & 6 & 7 & 8 & 9 & 10 & 11 & 12 & 13 & 14 & 15 \\
\hline 13 & 760 & 2 & 60 & 1.5 & 80 & 1 & 85.73 & 85.4 & 70.3 & 63.72 & 14.81 & 14.45 & 80.13 & 70.07 \\
\hline 14 & 760 & 2.5 & 20 & 2 & 95 & 2 & 86.11 & 85.31 & 73.33 & 76.93 & 19.08 & 20.7 & 81.11 & 90.98 \\
\hline 15 & 760 & 3 & 30 & 2.5 & 20 & 3 & 87.80 & 87.18 & 73.85 & 74.41 & 15.2 & 14.22 & 70.5 & 64.8 \\
\hline 16 & 860 & 1 & 50 & 1.5 & 95 & 3 & 85.77 & 86.57 & 53.33 & 62.08 & 12.78 & 12.01 & 49.39 & 52.68 \\
\hline 17 & 860 & 1.5 & 60 & 2 & 20 & 4 & 83.58 & 83.6 & 50.21 & 56.12 & 11.62 & 12.05 & 44.91 & 51.23 \\
\hline 18 & 860 & 2 & 20 & 2.5 & 40 & 5 & 83.85 & 83.51 & 63.33 & 71.31 & 22.47 & 17.6 & 82.49 & 71.37 \\
\hline 19 & 860 & 2.5 & 30 & 3 & 60 & 1 & 85.44 & 85.34 & 58.46 & 69.05 & 10.07 & 14.48 & 39.97 & 61.13 \\
\hline 20 & 860 & 3 & 40 & 1 & 80 & 2 & 85.06 & 84.64 & 74.28 & 68.86 & 10.5 & 12.65 & 52.75 & 57.27 \\
\hline 21 & 960 & 1 & 60 & 2.5 & 60 & 2 & 81.95 & 82.11 & 60.12 & 57.53 & 7.75 & 9.001 & 35.94 & 39.15 \\
\hline 22 & 960 & 1.5 & 20 & 3 & 80 & 3 & 82.03 & 82.02 & 66.67 & 61.17 & 19.37 & 17.14 & 74.86 & 59.54 \\
\hline 23 & 960 & 2 & 30 & 1 & 95 & 4 & 83.48 & 83.82 & 52.31 & 56.34 & 18.6 & 16.57 & 61.1 & 56.97 \\
\hline 24 & 960 & 2.5 & 40 & 1.5 & 20 & 5 & 83.05 & 83.14 & 57.14 & 57.45 & 15.5 & 12.02 & 59.9 & 45.19 \\
\hline 25 & 960 & 3 & 50 & 2 & 40 & 1 & 81.75 & 81.12 & 64.31 & 64.90 & 8.5 & 9.131 & 39.42 & 41.68 \\
\hline \multicolumn{7}{|c|}{$R$} & \multicolumn{2}{|c|}{0.9846} & \multicolumn{2}{|c|}{0.7270} & \multicolumn{2}{|c|}{0.8044} & \multicolumn{2}{|c|}{0.8429} \\
\hline & & & $\overline{t_{R}}$ & & & & \multicolumn{2}{|c|}{610.8173} & \multicolumn{2}{|c|}{29.3006} & \multicolumn{2}{|c|}{43.3080} & \multicolumn{2}{|c|}{57.3464} \\
\hline
\end{tabular}

The batch for roasting was prepared by mixing the sample of commercial product, which was the same in all experiments, and sodium carbonate according to its consumption. Thus, the mass of the batch was variable depending on the consumption of $\mathrm{Na}_{2} \mathrm{CO}_{3}$.

During the mathematical processing of the experimental data, the yield of the sinter $\left(\beta_{\text {sinter }}, \%\right)$, the yield of cake calculated with respect to the mass of the sinter $\left(\beta_{\text {cakesinter, }} \%\right)$, the yield of cake, found with respect to the mass of the initial batch $\left(\beta_{\text {batch }}, \%\right)$, chromium content in the sinter $\left(\mathrm{Cr}_{\text {sinter }}, \%\right)$, in the cake $\left(\mathrm{Cr}_{\text {cake }}, \%\right)$ and in the batch $\left(\mathrm{Cr}_{\text {batch }}, \%\right)$, chromium recovery in the cake $\left(\varepsilon_{\text {cake }}, \%\right)$ and in the solution $\left(\varepsilon_{\text {sol }}, \%\right)$ were determined. The relationship between these variables is determined by the following relationships:

$$
\begin{gathered}
b_{\text {sinter }}=\frac{m_{\text {sinter }} \times 100}{m_{\text {bach }}} ; \\
\beta_{\text {cakelsinter }}=\frac{m_{\text {cake }} \cdot 100}{m_{\text {sinter }}} ; \\
\beta_{\text {cakelbatch }}=\frac{m_{\text {cake }} \cdot 100}{m_{\text {batch }}},
\end{gathered}
$$

where $m_{\text {sinter }}, m_{\text {batch }}, m_{\text {cake }}$ - are the mass of the sinter, batch and cake, respectively. Using the formulas (1)-(3), we find:

$$
\beta_{\text {cake/batch }}=\frac{\beta_{\text {sinter }} \cdot \beta_{\text {cake/sinter }}}{100} .
$$

The recovery of chromium into the sinter is equal to $100 \%$, which is calculated by the formula:

$$
\varepsilon_{\text {sinter }}=\frac{\beta_{\text {sinter }} \cdot \mathrm{Cr}_{\text {sinter }}}{\mathrm{Cr}_{\text {batch }}}=100 \text {. }
$$

The extraction of chromium into a cake is determined by:

$$
\varepsilon_{\text {cake }}=\frac{\beta_{\text {cake/sinter }} \cdot \mathrm{Cr}_{\text {cake }}}{\mathrm{Cr}_{\text {sinter }}} \text {. }
$$

According to (5) the chromium content in the sinter $\mathrm{Cr}_{\text {sinter }}$ is:

Substituting this expression to (6), we find:

$$
\mathrm{Cr}_{\text {sinter }}=\frac{100 \cdot \mathrm{Cr}_{\text {batch }}}{\beta_{\text {sinter }}} .
$$

$$
\varepsilon_{\text {cake }}=\frac{\beta_{\text {cake/sinter }} \cdot \beta_{\text {sinter }} \mathrm{Cr}_{\text {cake }}}{100 \cdot \mathrm{Cr}_{\text {batch }}}
$$

or, taking into account (4):

$$
\varepsilon_{\text {cake }}=\frac{\beta_{\text {cakelbatch }} \cdot \mathrm{Cr}_{\text {cake }}}{\mathrm{Cr}_{\text {batch }}}
$$


The extraction of chromium to the solution is:

$$
\varepsilon_{\mathrm{p}}=100-\varepsilon_{\mathrm{K}} .
$$

Thus, the functions under consideration are related to each other and are interdependent, which is reflected on the form of the partial functions obtained in the process of their graphic representation. So, $\beta_{\text {cakelbatch }}$ depends on $\beta_{\text {sinter }}$ and $\beta_{\text {cake/sinter }}(4)$, and the extraction of chromium in the cake (8) is determined by the mutual influence of the four dependent variables such as $\beta_{\text {cakessinter }}, \beta_{\text {sinter }}, \mathrm{Cr}_{\text {cake }}$ and $\mathrm{Cr}_{\text {batch }}$.

Table 2

\section{Partial dependencies}

\begin{tabular}{|c|c|c|}
\hline Function's name & No. & Equation in logarithmic form \\
\hline Yeild of sinter, $\beta_{\text {sinter }}$ & $\begin{array}{l}1 \\
2 \\
3\end{array}$ & $\begin{array}{l}\ln \beta_{\text {sinter } 1}=6.0942-2.4873 \cdot 10^{-1} \ln t_{\text {roast. }} \\
\ln \beta_{\text {sinter } 2}=4.4708-2.6092 \cdot 10^{-2} \ln \tau_{\text {roast. }} \\
\ln \beta_{\text {sinter } 3}=3.8181-7.1847 \cdot 10^{-3} N+0,254 \ln N\end{array}$ \\
\hline $\begin{array}{l}\text { Yield of cake form mass of the batch, } \\
\beta_{\text {cake/batch }}\end{array}$ & $\begin{array}{l}1 \\
2 \\
3 \\
4 \\
5 \\
6\end{array}$ & $\begin{array}{l}\ln \beta_{\text {cake/batch } 1}=-9.6171-3.7299 \cdot 10^{-3} t_{\text {roast. }}+2.5116 \ln t_{\text {roast. }} \\
\ln \beta_{\text {cake/batch } 2}=3.8216+0.3401 \tau_{\text {roast. }}-0.5418 \ln \tau_{\text {roast. }} \\
\ln \beta_{\text {cake/batch } 3}=4.6975-0.1475 \ln N \\
\ln \beta_{\text {cake/batch } 4}=4.3054-0.1691 \tau_{b}+0.3149 \ln \tau_{\text {leach. }} \\
\ln \beta_{\text {cake/batch } 5}=3.4662-4.7599 \cdot 10^{-3} t_{\text {leach. }}+0.25013 \ln t_{\text {leach. }} \\
\ln \beta_{\text {cake/batch } 6}=4.1637\end{array}$ \\
\hline Content of chromium in the cake, $\mathrm{Cr}_{\text {cake }}$ & $\begin{array}{l}1 \\
2 \\
3 \\
4 \\
5 \\
6\end{array}$ & 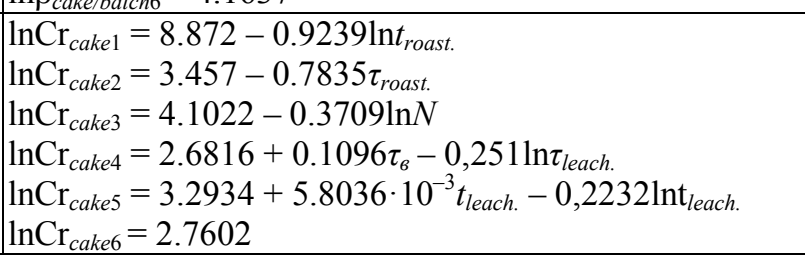 \\
\hline Extraction of chromium into a cake, $\varepsilon_{\text {cake }}$ & $\begin{array}{l}1 \\
2 \\
3 \\
4 \\
5 \\
6\end{array}$ & $\begin{array}{l}\ln \varepsilon_{\text {cake } 1}=-3.4544-3.7299 \cdot 10^{-3} t_{\text {roast. }}+1.5877 \ln t_{\text {roast. }} \\
\ln \varepsilon_{\text {cake } 2}=4.5667-0.4434 \tau_{\text {roast }}+0.8582 \ln \tau_{\text {roast. }} \\
\ln \varepsilon_{\text {cake } 3}=5.8029+7.1788 \cdot 10^{-3} N-0.5184 \ln N \\
\ln \varepsilon_{\text {cake } 4}=4.2935-5.95 \cdot 10^{-2} \tau_{\text {leach. }}+6.39 \cdot 10^{-2} \ln \tau_{\text {leach. }} \\
\ln \varepsilon_{\text {cake } 5}=4.0466+1.0437 \cdot 10^{-3} t_{\text {leach. }}+2.69 \cdot 10^{-2} \ln t_{\text {leach. }} \\
\ln \varepsilon_{\text {cake } 6}=4.2143\end{array}$ \\
\hline
\end{tabular}

Note. the partial dependencies $\ln \varepsilon_{\text {cake. } i}=f\left(x_{i}\right)$, where $i$ is the number of the dependence, are obtained by substituting the arithmetic mean values $x_{i \text {.mean }}$ and $\left(\ln x_{i}\right)_{\text {mean }}$ to (16), excluding those mean values that are the argument of the sought expression.

In order to simplify the procedure for finding the required equations, all the particular and multifactor dependencies will be represented as functions of the logarithms of the controllable indicators. The dotted partial dependences (presented after the potentiation in Fig. 1-4) are described mathematically (see Table 2) and then we reduce these formulas according to [9] to generalized equations.

$$
\begin{aligned}
& \ln \beta_{\text {sinter }}= 5.002-0.2487 \ln t_{\text {roast. }}-2.6092 \cdot 10^{-2} \ln \tau_{\text {roast. }}-7.1847 \cdot 10^{-3} N+0.254 \ln N . \\
& \ln \beta_{\text {cakel batch }}=-9.9813-3.7299 \cdot 10^{-3} t_{\text {roast. }}+2.5116 \ln t_{\text {roass. }}+0.3401 \tau_{\text {roast. }}-0.5418 \ln \tau_{\text {roast. }}- \\
&-0.1475 \ln N-0.1691 \tau_{\text {leach. }}+0.3149 \ln \tau_{6}-4.7599 \cdot 10^{-3} t_{\text {leach. }}+0.2501 \ln t_{\text {leach. }} . \\
& \ln \mathrm{rr}_{\text {cake }}=11.3654-0.9239 \ln t_{\text {roast. }}-0.7835 \tau_{\text {roast. }}+1,4 \ln \tau_{\text {roast. }}-0,3709 \ln N+ \\
& \quad+0.1096 \tau_{\text {leach. }}-0.251 \ln \tau_{\text {leach. }}+5.8036 \cdot 10^{-3} t_{\text {leach. }}-0.2232 \ln t_{\text {leach. }} .
\end{aligned}
$$

For the convenience of the following operations, we describe the dependence of the chromium content in the batch on the consumption of $\mathrm{Na}_{2} \mathrm{CO}_{3}$ by an equation of the form:

After logarithm (9), we find:

$$
\ln \mathrm{Cr}_{\text {batch }}=2.9859-7.1788 \cdot 10^{-3} \mathrm{~N} \text {. }
$$

$$
\ln \varepsilon_{\text {cake }}=\ln \beta_{\text {cakelbatch }}+\ln \mathrm{Cr}_{\text {cake }}-\ln \mathrm{Cr}_{\text {batch }} .
$$

Further, substituting expressions (12)-(14) in (15) we obtain:

$$
\begin{aligned}
& \ln \varepsilon_{\text {cake }}=-1.6018-3.7299 \cdot 10^{-3} t_{\text {roast. }}+1.5877 \ln t_{\text {roast. }}-0.4434 \tau_{\text {roast. }}+0.8582 \ln \tau_{\text {roast. }}+ \\
& +7.1788 \cdot 10^{-3} N-0.5184 \ln N-0.0595 \tau_{\text {leach. }}+0,0639 \ln \tau_{\text {leach. }}+1,0437 \cdot 10^{-3} t_{\text {leach. }}+0.0269 \ln t_{\text {leach. }} .
\end{aligned}
$$

In the present commercial product, chromium is present mainly in the form of chromospinelide, which are $\mathrm{MgCr}_{2} \mathrm{O}_{4}, \mathrm{FeCr}_{2} \mathrm{O}_{4}, \mathrm{Fe}(\mathrm{Al}, \mathrm{Cr})_{2} \mathrm{O}_{4},(\mathrm{MgFe})(\mathrm{Al}, \mathrm{Cr}, \mathrm{Fe})_{2} \mathrm{O}_{4}$. 
As a rule, when writing the reaction equations that occur during the roasting of batch that contains chromospinelides, the behavior of the oxides composing this batch is considered [9]. These reactions have the form:

$$
\begin{gathered}
\mathrm{FeCr}_{2} \mathrm{O}_{4}+2 \mathrm{Na}_{2} \mathrm{CO}_{3}+1,75 \mathrm{O}_{2}=2 \mathrm{Na}_{2} \mathrm{CrO}_{4}+0,5 \mathrm{Fe}_{2} \mathrm{O}_{3}+2 \mathrm{CO}_{2} \\
\mathrm{MgCr}_{2} \mathrm{O}_{4}+2 \mathrm{Na}_{2} \mathrm{CO}_{3}+1,5 \mathrm{O}_{2}=2 \mathrm{Na}_{2} \mathrm{CrO}_{4}+\mathrm{MgO}+2 \mathrm{CO}_{2} \\
\mathrm{MgCr}_{2} \mathrm{O}_{4}+\mathrm{MgO}+1,5 \mathrm{O}_{2}=2 \mathrm{MgCrO}_{4} \\
\mathrm{Na}_{2} \mathrm{CrO}_{4}+\mathrm{MgO}+\mathrm{CO}_{2}=\mathrm{MgCrO}_{4}+\mathrm{Na}_{2} \mathrm{CO}_{3}
\end{gathered}
$$

The list of reactions that occur during roasting of chromium-containing materials includes:

$$
\begin{gathered}
\mathrm{Al}_{2} \mathrm{O}_{3}+\mathrm{Na}_{2} \mathrm{CO}_{3}=\mathrm{Na}_{2} \mathrm{Al}_{2} \mathrm{O}_{4}+\mathrm{CO}_{2} \\
\mathrm{SiO}_{2}+\mathrm{Na}_{2} \mathrm{CO}_{3}=\mathrm{Na}_{2} \mathrm{SiO}_{3}+\mathrm{CO}_{2} \\
\mathrm{FeCr}_{2} \mathrm{O}_{4}+2 \mathrm{Na}_{2} \mathrm{SiO}_{3}+1,5 \mathrm{O}_{2}=2 \mathrm{Na}_{2} \mathrm{CrO}_{4}+0,5 \mathrm{Fe}_{2} \mathrm{SiO}_{4}+1,5 \mathrm{SiO}_{2} \\
2 \mathrm{Na}_{2} \mathrm{SiO}_{3}+2 \mathrm{Al}_{2} \mathrm{O}_{3}=\mathrm{Na}_{2} \mathrm{O} \cdot \mathrm{Al}_{2} \mathrm{O}_{3} \cdot 2 \mathrm{SiO}_{2}+\mathrm{Na}_{2} \mathrm{Al}_{2} \mathrm{O}_{4}
\end{gathered}
$$

A noticeable interaction of magnesium and iron chromites with sodium carbonate (17)-(18) takes place already at a temperature of $600{ }^{\circ} \mathrm{C}$. As the temperature rises, the degree of interaction of these components increases. Reactions (19)-(20) occur at relatively low temperatures. Reactions (21)-(22) begin at a temperature of $710-720^{\circ} \mathrm{C}$. The form of the obtained partial dependences (Fig. 1-4) is determined by the degree of completion of the reactions listed. Thus, the decreasing dependence of the yield of the sinter on temperature reflects the process of loss of the mass of the batch due to the transition to the gaseous phase of carbon dioxide. The roasting time affects the process to a lesser extent. The presence of an extremum in the dependence of the yield of the sinter on the consumption of sodium carbonate is the result of a purely mathematical effect: the mass of the sinter increases with increasing consumption of $\mathrm{Na}_{2} \mathrm{CO}_{3}$. This law is described by a power function. The weight of the batch also increases, but is directly proportional to this parameter. As a result, the dependence of the yield of the sinter, which is a quotient of the fission mass divided by the weight of the batch (1), is obtained with an extremum.
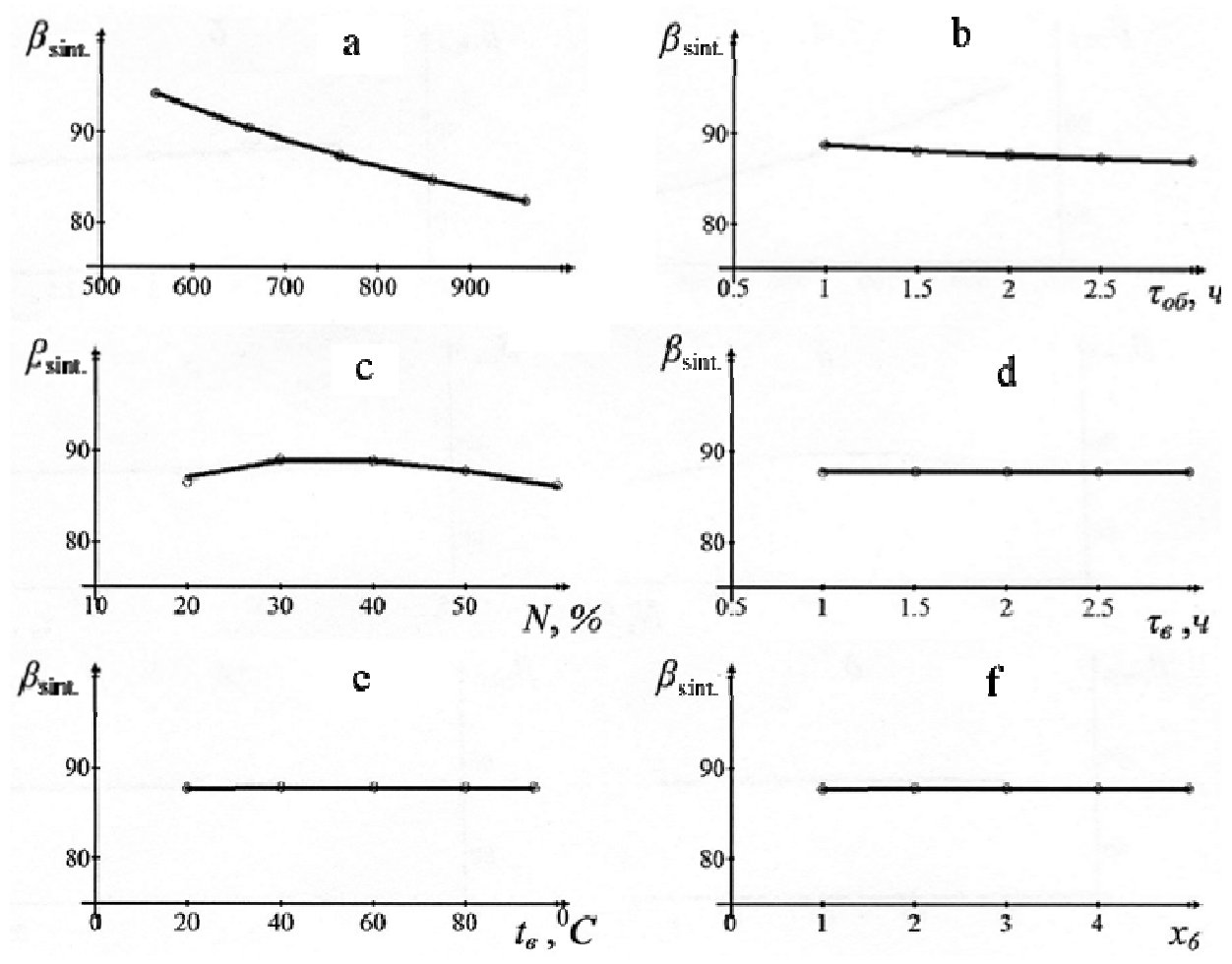

$$
\begin{aligned}
& a \text { - from the roasting temperature }\left(t_{\text {roast. }},{ }^{\circ} \mathrm{C}\right) ; b-\text { from the roasting time }\left(\tau_{\text {roast. }}, h\right) ; \\
& c \text { - from the consumption of } \mathrm{Na}_{2} \mathrm{CO}_{3}(N, \%) ; d-\text { from leaching time }\left(\tau_{\text {leaching }}, h\right) ; \\
& e \text { - from the leaching temperature }\left(t_{\text {leaching }},{ }^{\circ} \mathrm{C}\right) ; f \text { - from the vacant factor }\left(x_{6}\right)
\end{aligned}
$$

Figure 1. Partial dependences of the yield of the sinter $\left(\beta_{\text {sinter }}, \%\right)$ 

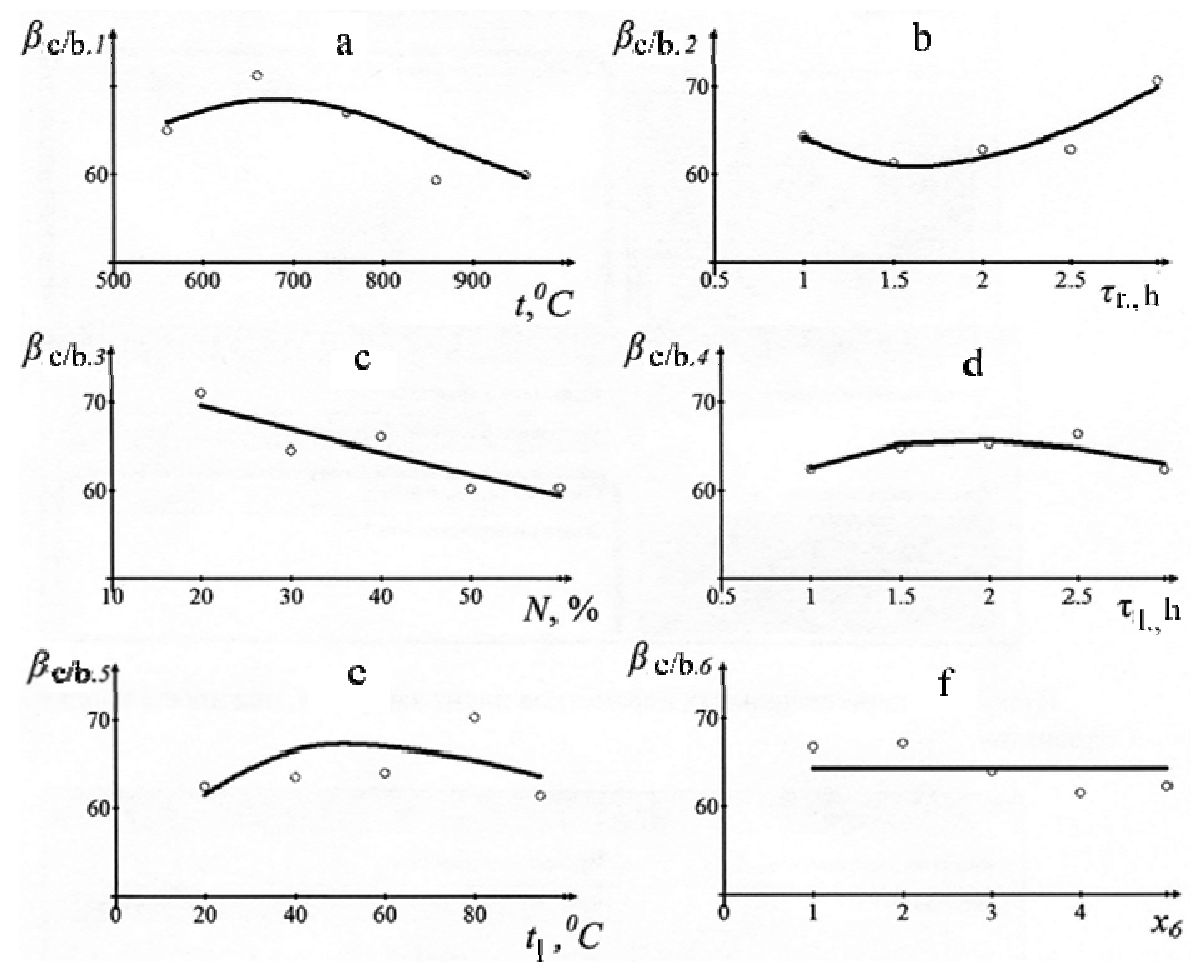

$a$ - from the roasting temperature $\left(t_{\text {roast } .},{ }^{\circ} \mathrm{C}\right) ; b$ - from the roasting time $\left(\tau_{\text {roast. }}, h\right)$;

$c$ - from the consumption of $\mathrm{Na}_{2} \mathrm{CO}_{3}(N, \%) ; d$ - from leaching time $\left(\tau_{\text {leaching }}, h\right)$; $e$ - from the leaching temperature $\left(t_{\text {leaching }},{ }^{\circ} \mathrm{C}\right) ; f$ - from the vacant factor $\left(x_{6}\right)$

Figure 2. Partial dependencies of cake output $\left(\beta_{\text {cake/batch }}, \%\right)$
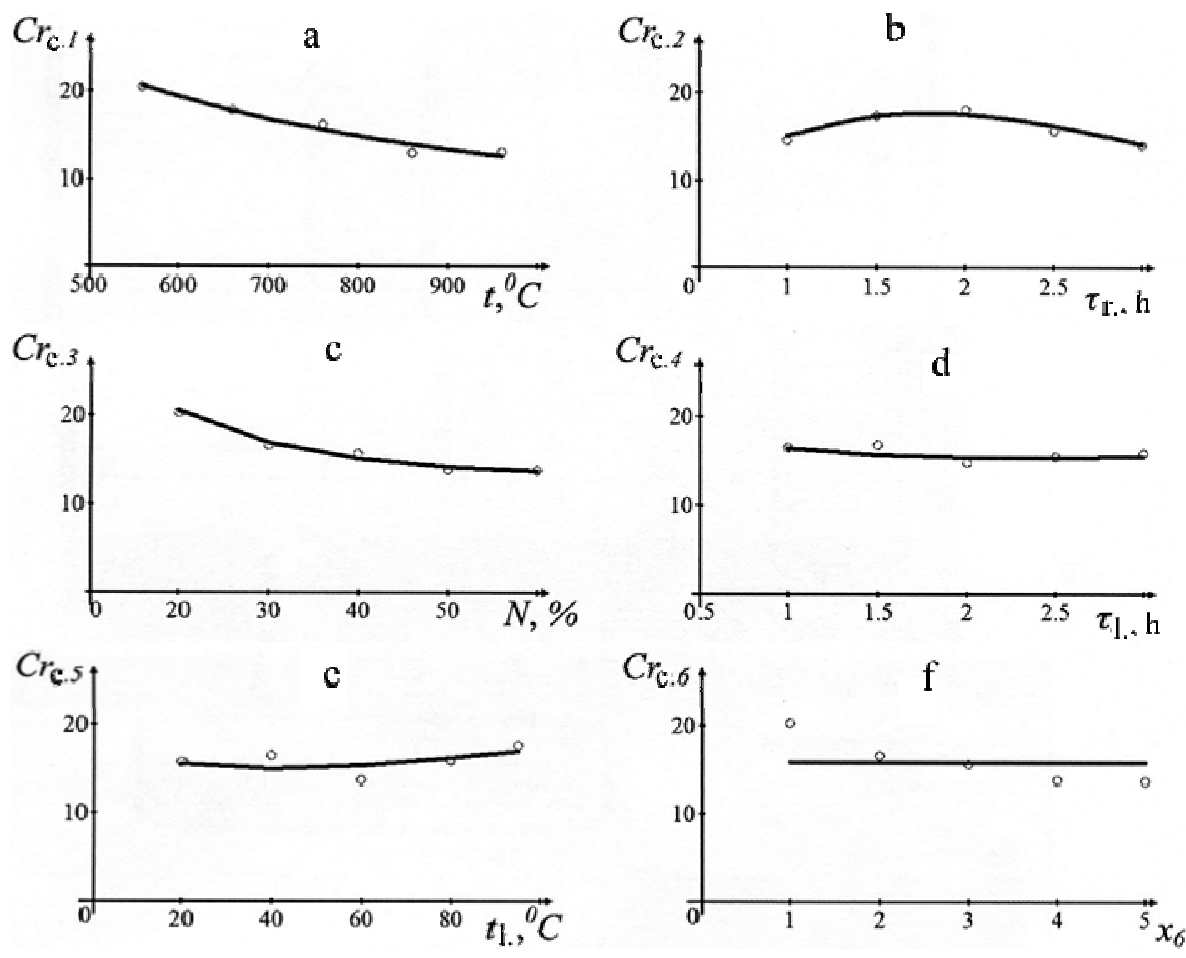

$a$ - from the roasting temperature $\left(t_{\text {roast. }},{ }^{\circ} \mathrm{C}\right) ; b$ - from the roasting time $\left(\tau_{\text {roast. }}, h\right)$;

$c$ - from the consumption of $\mathrm{Na}_{2} \mathrm{CO}_{3}(N, \%) ; d$ - from leaching time $\left(\tau_{\text {leaching }}, h\right)$; $e$ - from the leaching temperature $\left(t_{\text {leaching }},{ }^{\circ} \mathrm{C}\right) ; f$ - from the vacant factor $\left(x_{6}\right)$

Figure 3. Partial dependences of the chromium content in the cake $\left(\mathrm{Cr}_{\text {cake }}, \%\right)$ 

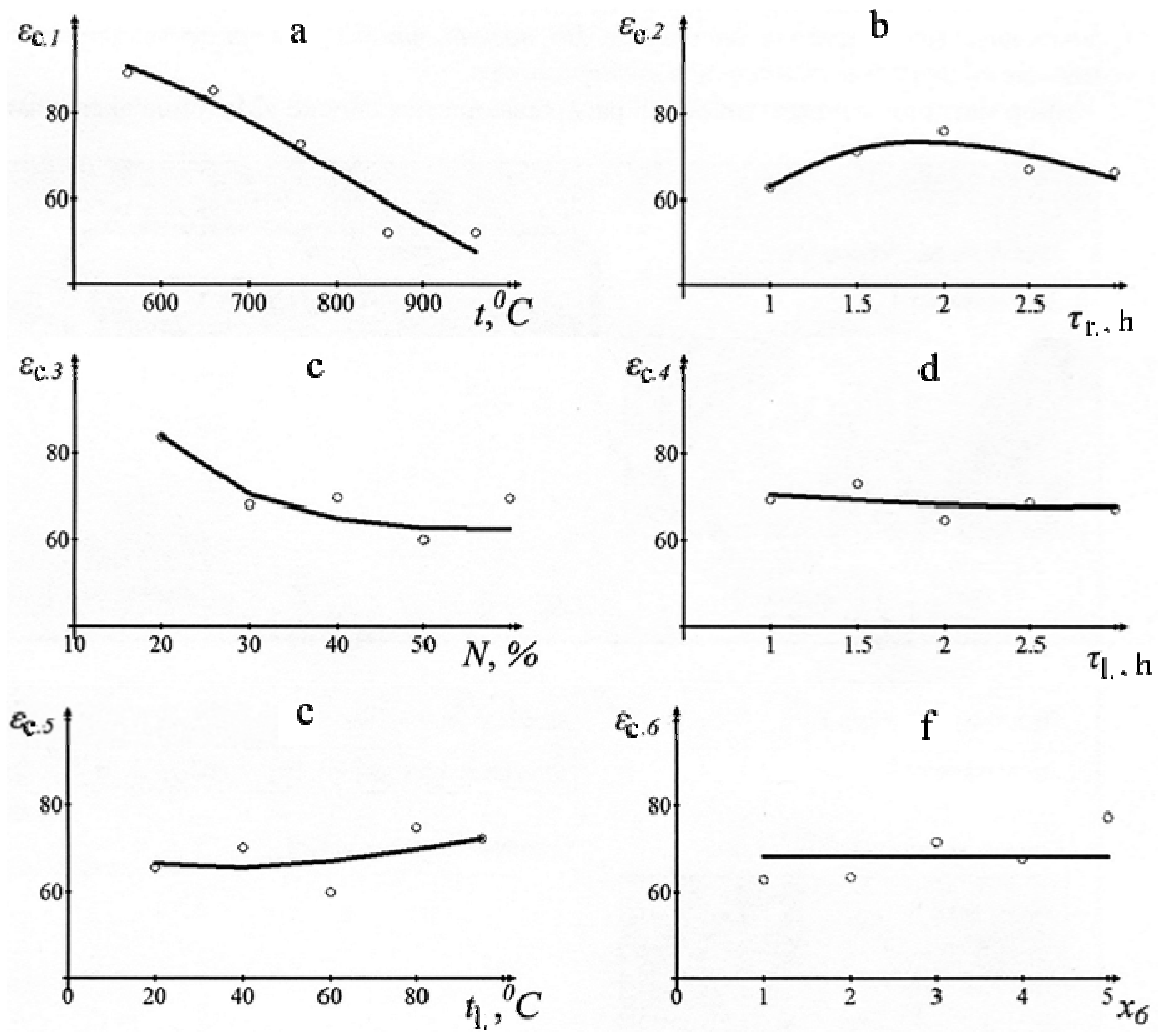

$a$ - from the roasting temperature $\left(t_{\text {roast. }},{ }^{\circ} \mathrm{C}\right) ; b$ - from the roasting time $\left(\tau_{\text {roast. }}, h\right)$;

$c$ - from the consumption of $\mathrm{Na}_{2} \mathrm{CO}_{3}(N, \%) ; d$ - from leaching time $\left(\tau_{\text {leaching }}, h\right)$;

$e$ - from the leaching temperature $\left(t_{\text {leaching }},{ }^{\circ} \mathrm{C}\right) ; f$ - from the vacant factor $\left(x_{6}\right)$

Figure 4. Partial dependencies of chromium extraction in the cake $\left(\varepsilon_{\text {cake }}, \%\right)$

The dependence of the cake yield on the roasting temperature (Fig. 2a) has an ascending and descending branch. The increase in the cake yield in the range of $560-700{ }^{\circ} \mathrm{C}$ is due to the transition to the solution of that portion of $\mathrm{Na}_{2} \mathrm{CO}_{3}$, which did not react at low calcination temperatures. This part of $\mathrm{Na}_{2} \mathrm{CO}_{3}$ decreases with a temperature change from 560 to $700^{\circ} \mathrm{C}$. Accordingly, the yield of cake increases. An increase in the cake yield in this temperature range is also associated with the passage of reactions (19)-(20). The downward branch of the present dependence characterizes the increase in the fraction of soluble compounds as the roasting temperature rises.

It is known [9] that formation of $\mathrm{MgCrO}_{4}$ is possible at relatively low temperatures $\left(700-800{ }^{\circ} \mathrm{C}\right) \mathrm{ac}-$ cording to the reactions (19)-(20), as well as iron silicate (23) and nepheline (24). It is likely that an increase in the cake yield with the largest roasting time of $3 \mathrm{~h}$ is due to the formation of these compounds. A change in the consumption of $\mathrm{Na}_{2} \mathrm{CO}_{3}$ in interval $20-60 \%$ leads to a decrease in $\beta_{\text {cake/batch }}$ due to the increase in the amount of soluble compounds in the sinter. The leaching time and the temperature of this process have practically no effect on the yield of cake.

The content of chromium in the cake and its extraction into the latter (Fig. 3, 4) are determined by the simultaneous occurrence of the above reactions and those changes in the interdependent technological parameters (the yield of cake and sinter, the content of chromium in the cake), which are due to these reactions. With increasing of roasting temperature, the chromium content in the cake $\mathrm{Cr}_{\text {cake }}$ and its extraction into a product $\varepsilon_{\text {cake }}$ decrease monotonically. The same effect occurs when the consumption of $\mathrm{Na}_{2} \mathrm{CO}_{3}$ increases. The dependences of $\mathrm{Cr}_{\text {cake }}$ and $\varepsilon_{\text {cake }}$ on the roasting time characterize the processes of passing the reactions of formation of sparingly soluble compounds in the interval of $1-2 \mathrm{~h}$ (the chromium content in the cake and the extraction of chromium in it increase) and the increase in the fraction of soluble compounds during roasting for a time longer than $2 \mathrm{~h}$. The leaching conditions practically do not affect the monitored indicators.

Analysis of the partial dependences obtained (Fig. 4) shows that in order to achieve the minimum recovery of chromium in a cake and, accordingly, the most complete extraction of metal into a solution, roast- 
ing should be carried out under the following conditions such as $t_{\text {roast. }}=960^{\circ} \mathrm{C}, \tau_{\text {roast. }}=3 \mathrm{~h}, N=60 \%$, and leaching — at $\tau_{\text {leach. }}=2 \mathrm{~h}$ and $\mathrm{t}_{\text {leach. }}=60{ }^{\circ} \mathrm{C}$.

According to the calculation from (16), the recovery of chromium into the cake under these conditions is $42.06 \%$, and in the solution $57.94 \%$. An increase in the latter index can be achieved if the abovementioned limits of the change in the roasting conditions are exceeded, that is, when the temperature is raised to $1100-1200{ }^{\circ} \mathrm{C}$ - the time of this operation is up to $4-5 \mathrm{~h},-$ and the sodium carbonate consumption is to $70-80 \%$. Since the leaching parameters have the least effect on the results of the experiments, it is advisable to leave the above values unchanged, namely $\tau_{\text {leach. }}=2 \mathrm{~h}, \mathrm{t}_{\text {leach. }}=60^{\circ} \mathrm{C}$. The calculation for these calcination conditions shows (Table 3 ) that the recovery of chromium in the solution increases with an increase in the roasting temperature, the time it takes, and the consumption of $\mathrm{Na}_{2} \mathrm{CO}_{3}$. At the same time, as far as the limit values of factors set in the plan (Table 1) are removed, the accuracy of forecasts decreases.

Ta a le 3

Extraction of chromium into the cake $\left(\varepsilon_{\text {cake }}\right)$ and solution $\left(\varepsilon_{\text {sol }}\right)$. The calculation data for (16), (10) $-\varepsilon_{\text {cake.t }}, \varepsilon_{\text {sol.t }}$ and experimental data $-\varepsilon_{\text {cake.ex. }}, \varepsilon_{\text {sol.ex. }}$

\begin{tabular}{|c|c|c|c|c|c|c|c|}
\hline No. & $t_{\text {roast. }}{ }^{\circ} \mathrm{C}$ & $t_{\text {roast. }}, \mathrm{h}$ & $N, \%$ & $\varepsilon_{\text {cake.t }}$ & $\varepsilon_{\text {cake.ex }}$ & $\varepsilon_{\text {sol.t }}$ & $\varepsilon_{\text {sol.ex. }}$ \\
\hline 1 & 960 & 3 & 60 & 42.06 & 39.42 & 57.94 & 60.58 \\
\hline 2 & 1000 & 4 & 70 & 31.50 & 30.81 & 68.50 & 69.19 \\
\hline 3 & 1100 & 4 & 70 & 25.24 & 23.46 & 74.76 & 76.54 \\
\hline 4 & 1200 & 4 & 70 & 19.95 & 15.48 & 80.05 & 84.52 \\
\hline 5 & 1200 & 5 & 80 & 15.55 & 8.32 & 84.45 & 91.68 \\
\hline
\end{tabular}

Thus, using the method of stochastic-determininated design of experiment in a modified version, a fivefactor mathematical model of chromium extraction into a cake was obtained. In the derivation of this model, there was used a method that includes the preliminary finding of two multifactorial equations which describing the influence on the output of cake $\left(\beta_{\text {cakelbatch }}\right)$ and the content of chromium in it $\left(\mathrm{Cr}_{\text {cake }}\right)$ from the specified factors (roasting temperature and time of this operation, consumption of $\mathrm{Na}_{2} \mathrm{CO}_{3}$, temperature and leaching time of chromium from the cake), with the subsequent substitution of these equations into a formula linking $\varepsilon_{\text {cake }}, \beta_{\text {cake/batch }}, \mathrm{Cr}_{\text {cake }}, \mathrm{Cr}_{\text {batch }}$. The suitability of the desired equation for making predictions that are more accurate when introducing into a given equation the values of the arguments within the given limits of their variation and less accurate at a considerable distance from these limits is shown.

\section{References}

1 Хром Казахстана: справочник / Под ред. М.И. Гасика, В.И. Гринько, В.Н. Шошкина. - М.: Металлургия, 2001. $416 \mathrm{c}$.

2 Техногенное минеральное сырье рудных месторождений Казахстана: справочник / Под ред. А.А. Абдулина, С.Ж. Даукеева и др. - Алматы: Изд. Ин-та геол. наук им. К. Сатпаева, 2000. — 122 с.

3 Сарсенов А.М. Экологическая безопасность и ресурсосбережение при переработке хромитовых и боратовых руд / А.М. Сарсенов. - Алматы: Высш. шк., 2000. - 233 с.

4 Сарсенов А.М. Пути решения проблем загрязнения северо-востока бассейна Каспийского моря бором и хромом / A.М. Сарсенов, Р.Т. Шукуров // [ЭР]. Режим доступа: http://asu.edu.ru/images/File/Izdatelstvo/URV2/37.pdf.

5 Рябин В.А. Современные технологи переработки хромовых руд, нейтрализации и утилизации токсичных отходов / В.А. Рябин, М.Я. Попильский, А.А. Солошенко и др. // Техноген-97: Сб. науч.-техн. конф. по переработке техногенных образований. - Екатеринбург, 1997. - С. 59-61.

6 Плышевский Ю.С. О переработке некоторых техногенных отходов / Ю.С. Плышевский, Н.В. Гаркунова, К.В. Ткачев // Тр. УНИХИМ. - Екатеринбург, 2005. - Вып. 72.— С. 20-25// http://unichim.ru/back/tmp_file/820363491.pdf

7 Плышевский Ю.С. Переработка шлама хроматного производства / Ю.С. Плышевский, А.А. Солошенко, Н.В. Гаркунова и др. // Уралэкология — Техноген-2000: Тезисы докл. науч.-техн. конф. — Екатеринбург, 2000. — C. $186-187$.

8 Беляев С.В. Пути развития вероятностно-детерминированного планирования эксперимента / С.В. Беляев, В.П. Малышев // Комплексная переработка минерального сырья Казахстана. Состояние, проблемы, решения: [В 10 т.] Т. 9. Информационные технологии в минерально-сырьевом комплексе. Гл. 8. - Алматы, 2008. - С. 599-633.

9 Авербух Т.Д. Технология соединений хрома / Т.Д. Авербух, П.Г. Павлов. - Л.: Химия, 1967. - 376 с. 


\title{
Н.А. Каргина, В.Н. Фомин \\ Хромкұрамды техногендік материалдарды өндеудің технологиялық үрдісін дайындау
}

\begin{abstract}
Мақала натрий карбонаты қатысында күйдіру және әрі қарай күйіктен хромды сумен сілтілендіруден тұратын хромқұрамды техногендік материалдарды өндеудің технологиялық үрдісін дайындауға арналған. Тәжірибені ықтималды-детерминді жоспарлау әдісін қолдану арқылы хромды кекке бөліп алудың бесфакторлы математикалық үлгісі алынды. Хромды кекке аз мөлшерде өтуіне қолжеткізу және сәйкесінше аталған металды толығымен ерітіндіге көшіру үшін шихтаны күйдіруді келесі

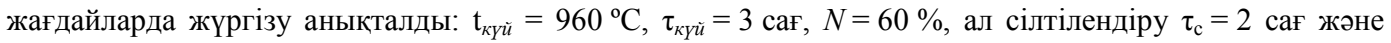
$\mathrm{t}_{\mathrm{c}}=60^{\circ} \mathrm{C}$. Жүретін үрдістердің химизмі келтірілді. Алынған математикалық теңдеудің берілген өзгеру шегіндегі аргументтердің мәнін теңдеуге енгізуге барысында және осы шектен алыстату барысында нақты мәндерді алуға болатындығын болжауға болатындығын көрсетеді. Аталған жағдайда есептеу ерітіндідегі хромның қалпына келу уақытын арттыру, атмосфераның температурасын жоғарылату, оны ұстау және $\mathrm{Na}_{2} \mathrm{CO}_{3}$ тұтынуы өсіп отырғандығын көрсетті.
\end{abstract}

Кілm сөздер: хромит, ықтималдықпен анықталған эксперименттерді жоспарлау, хромды шаймалау, натрий карбонаты, натрий хроматы, өндірістік хром бар қалдықтар, хромитті кальцинациялау, хромды күйдіру үрдісі.

\section{Н.А. Каргина, В.Н. Фомин}

\section{Разработка технологического процесса переработки хромсодержащих техногенных материалов}

\begin{abstract}
Статья посвящена разработке технологического процесса переработки хромсодержащих техногенных материалов, которая включает их обжиг в присутствии карбоната натрия и последующее выщелачивание водой хрома из спека. С применением метода вероятностно-детерминированного планирования эксперимента получена пятифакторная математическая модель извлечения хрома в кек. Определено, что для достижения наименьшего извлечения хрома в кек и соответственно наиболее полного выделения данного металла в раствор обжиг шихты следует вести в условиях: $t_{\text {об }}=960{ }^{\circ} \mathrm{C}, \tau_{\text {об }}=3$ ч, $N=60 \%$, а выщелачивание - при $\tau_{\mathrm{B}}=2$ ч и $\mathrm{t}_{\mathrm{B}}=60{ }^{\circ} \mathrm{C}$. Представлен химизм происходящих процессов. Показана пригодность полученного математического уравнения для составления прогнозов, более точных при введении в данное уравнение значений аргументов, находящихся в заданных пределах их изменения, и менее точных при значительном удалении от этих пределов. Расчет в указанных условиях обжига показывает, что извлечение хрома в раствор возрастает при увеличении температуры обжига, времени его ведения и расхода $\mathrm{Na}_{2} \mathrm{CO}_{3}$.
\end{abstract}

Ключевые слова: хромит, вероятностно-детерминированное планирование эксперимента, выщелачивание хрома, карбонат натрия, хромат натрия, промышленные хромосодержащие отходы, кальцинация хромита, обжиг хромосодержащей шихты.

\section{References}

1 Gasik, M.I., Grinko, V.I., \& Shoshkin, V.N. (Eds.). (2001). Khrom Kazakhstana [Chromium of Kazakhstan]. Moscow: Metallurhiia [in Russian].

2 Abdulin, A.A., \& Daukeev, S.Zh. (Eds.). (2000). Tekhnohennoe mineralnoe syre rudnykh mestorozhdenii Kazakhstana [Technogenic mineral stock of Kazakhstan ore deposits]. Almaty: Izd. Instituta heolohicheskikh nauk im. K. Satpaeva [in Russian].

3 Sarsenov, A.M. (2000). Ekolohicheskaia bezopasnost i resursosberezhenie pri pererabotke khromitovykh i boratovykh rud [Ecological safety and cost-effective use of resources in the chromite and borite ores processing]. Almaty: Vysshaia shkola [in Russian].

4 Sarsenov, A.M., \& Shukurov, R.T. Puti resheniya problem zahryazneniya severo-vostoka basseina Kaspiiskoho moria borom i khromom [Ways of solving problems of pollutions of northeast Kaspian sea basin by borone and chromium]. asu.edu.ru. Retrieved from: http://asu.edu.ru/images/File/Izdatelstvo/URV2/37.pdf [in Russian].

5 Ryabin, V.A., Popilskii, M.Ya., \& Soloshenko, A.A. et al. (1997). Sovremennye tekhnolohii pererabotki khromovykh rud, neitralizatsii i utilizatsii toksichnykh otkhodov [Modern technology of chromium ores processing, toxic wastes neutralization and utilization]. Proceedings from: Technogen'97. Nauchno-tekhnicheskaia konferentsiia po pererabotke tekhnohennykh obrazovanii Scientific and technical conference on processing technogenic formations (pp. 59-61). Ekaterinburg [in Russian].

6 Plyshevskii, Yu.S., Garkunova, N.V., \& Tkachev, K.V. (2005). O pererabotke nekotorykh tekhnohennykh otkhodov [About processing of technogenic wastes]. Trudy UNIHIM - USRChemI proceedings, 72, Ekaterinburg, http://unichim.ru/back/ tmp_file/820363491.pdf [in Russian]. 
7 Plyshevskii, Yu.S., Soloshenko, A.A., \& Garkunova, N.V. et al. (2000). Pererabotka shlama hromatnoho proizvodstva [Processing slime of chromate production]. Proceedings from: Uralecology - Technogen-2000. Nauchno-tekhnicheskaia konferentsiia Scientific and technical conference (pp. 186-187). Ekaterinburg [in Russian].

8 Beliaev, S.V., \& Malyshev, V.P. (2008). Puti razvitiia veroiatnostno-determinirovannoho planirovaniia eksperimenta [Ways of stochastic-determinated design of experiments development]. (Vols. 1-10; Vol. 9): Informatsionnye tehnolohii $v$ mineralnosyrievom komplekse - Information technologies in the mineral-raw complex, 8, Almaty [in Russian].

9 Averbukh, T.D., \& Pavlov, P.G. (1967). Tekhnolohiia soedinenii khroma [Technology of chromium compounds]. Leningrad: Khimiia [in Russian]. 